\title{
The Relationship Between Physical Activity and the Presence of Sarcopenia in Older Adults: A Taiwanese Cross-sectional Study
}

\section{Yun-Chen Ko}

Taipei City Hospital, Yangming Branch

\section{Wei-Chu Chie}

National Taiwan University

Tai-Yin Wu

Taipei City Hospital, Zhongxing branch

Chin-Yu Ho

Taipei City Hospital, Yangming Branch

Wen-Ruey Yu ( $\nabla$ tpechdxc45@gmail.com )

Taipei City Hospital, Yangming Branch

\section{Research Article}

Keywords: Physical Activity, Presence of Sarcopenia, Older Adults, Taiwanese

Posted Date: January 4th, 2021

DOI: https://doi.org/10.21203/rs.3.rs-137188/v1

License: (a) (i) This work is licensed under a Creative Commons Attribution 4.0 International License. Read Full License 


\section{Abstract}

To the best of our knowledge, none of Taiwanese studies on the relationship between physical activity (PA) and sarcopenia by the latest 2019 Asian Working Group for Sarcopenia (AWGS) cutoff points of sarcopenia has been published. We used the Taiwan version of international physical activity questionnaire-short version and the 2019 AWGS diagnostic criteria of sarcopenia to examine the relationship between PA and sarcopenia in older adults. Volunteers in this cross-sectional study were recruited from those attending senior health checkup program held at a regional hospital in Taipei City from May 2019 to Sep 2019. Muscle strength was assessed by grip strength, physical performance was assessed by usual gait speed on a 6-meter course, and muscle mass was measured by bioelectrical impedance analysis. Multiple logistic regression was used to analyze the relationship between PA and sarcopenia. 565 participants were recruited and data from 500 participants were used. 138 (27.6\%) participants were classified as having sarcopenia, which included 87 women and 51 men. Among women, compared with those with low PA, moderate to high PA protected against the risk of sarcopenia with the adjusted odds ratio $(\mathrm{aOR})=0.52(95 \% \mathrm{Cl}$ : 0.27-0.98, $\mathrm{p}$-value=0.043). As for men, the aOR was 0.34 (95\% Cl: 0.12-0.95, p-value=0.039). A significant protective effect of PA on sarcopenia was found among the older adults after adjusting for confounders, especially for the male participants.

\section{Background}

Sarcopenia describes an important change in body composition and function, which is characterized by age-related lean muscle mass decline and low muscle strength and/or performance. The consequences of sarcopenia are falls, fracture, disability, hospital admission or need for long-term care placement, poor quality of life, and even mortality, which lead to a heavy burden on an aging society ${ }^{1-3}$. Consequently, sarcopenia has been formally recognized as a muscle disease since 2016. In some countries, International Classification of Diseases, 10th Revision, Clinical Modification (ICD-10-CM) diagnosis code for sarcopenia, M62.84, could be used to bill for care ${ }^{4}$.

The prevalence of sarcopenia varied from 9.9-40.4\%, depending on the definition used ${ }^{5}$. The definition and diagnosis of sarcopenia was inconsistent. In 2014, the Asian Working Group for Sarcopenia (AWGS) recommended using low muscle mass plus low muscle strength and/or low physical performance to diagnose sarcopenia with the following cut-off values: height-adjusted appendicular skeletal muscle mass as $<7.0 \mathrm{~kg} / \mathrm{m}^{2}$ in men and as $<5.7 \mathrm{~kg} / \mathrm{m}^{2}$ in women by using bio-electrical impedance analysis (BIA), handgrip strength as $<26 \mathrm{~kg}$ in men and as $<18 \mathrm{~kg}$ in women, and usual gait speed as $<0.8 \mathrm{~m} / \mathrm{s}^{6}$. Recently, AWGS announced the 2019 diagnostic criteria of sarcopenia and revised the cut-off points of handgrip strength (<28 kg for men) and usual gait speed $(<1.0 \mathrm{~m} / \mathrm{s})^{7}$.

The risk factors of sarcopenia are multifactorial, such as aging, disease, malnutrition, and inactivity, etc. Physical activity (PA) is undoubtedly a protective factor for sarcopenia. The beneficial effects of PA on sarcopenia include: reduced apoptosis, reduced oxidative stress, anti-inflammation, improved insulinglucose dynamics, enhanced quality and quantity of muscle proteins and mitochondria, skeletal muscle 
hypertrophy, positive neuromuscular adaptations, and enhanced muscle blood supply ${ }^{8}$. In a systemic review including 37 randomized controlled studies (RCTs), PA increases muscle mass and function while interactive effect of nutrition on muscle function appears limited ${ }^{9}$. PA is one of the most important keys to prevent sarcopenia, which is a modifiable predictor and can improve the muscle quality and quantity 10 .

According to the World Health Organization (WHO), the definition of PA is any bodily movement produced by skeletal muscles that requires energy consumption ${ }^{11}$. Physical inactivity has been recognized as the fourth leading risk factor for global mortality ( $6 \%$ of deaths globally) ${ }^{12}$. WHO recommends the amount of PA should be at least 150 minutes of moderate aerobic PA or 75 minutes of vigorous aerobic one per week for older adults ${ }^{13}$.

PA assessment tools include report-based, monitor-based and criterion measures ${ }^{14}$. The majority of scientific evidence on the health benefits of PA has been accumulated with report-based measures predominantly. In many types of epidemiology studies, the main purpose was simply to classify individuals into general levels of PA participation. Report-based measures have been proven to provide sufficient accuracy to categorize individuals based on their level of PA ${ }^{15}$.

Among self-report questionnaires for PA measurement, international physical activity questionnaire-short version (IPAQ-S) was designed to be easily adapted in many languages and countries ${ }^{16}$. The validity and reliability of the Taiwan version of IPAQ-S has been verified ${ }^{1718}$. Some studies have explored the relationship between PA and sarcopenia in older adults ${ }^{19}$. The potential confounders are aging, body mass index (BMI), gender, education level, albumin level, insulin resistance, lipid profiles, hemoglobin, uric acid, alcohol drinking, smoking, and institutionalization.

The definition of sarcopenia and the ways to evaluate PA were inconsistent. Moreover, there were still discrepancies between some associated factors and sarcopenia. To the best of our knowledge, none of studies on the relationship between PA and sarcopenia by the latest AWGS cutoff points of sarcopenia has been published, even though in the Asian populations. Therefore, the primary aim of this study is to use the Taiwan version of IPAQ-S and the 2019 AWGS diagnostic criteria of sarcopenia to examine the relationship between PA and the presence of sarcopenia in older adults. The secondary aim is to identify other associated factors of sarcopenia.

\section{Methods}

\section{Study population}

We conducted a cross-sectional study. 565 volunteers were recruited from those attending the senior health checkup program held at a regional hospital in Taipei City from May 2019 to Sep 2019. Those who could not perform the physical evaluation or answer the IPAQ-S were excluded. Besides, we also excluded participants with invalid or missing data while we did data analysis. The study had been approved by the 
Taipei City Hospital Research Ethics Committee with the case number TCHIRB-10801017 and all the participants provided written informed consents. All methods were carried out in accordance with relevant guidelines and regulations of the Taipei City Hospital Research Ethics Committee.

\section{Measurements}

\section{Assessment of sarcopenia}

We defined sarcopenia according to the 2019 AWGS diagnostic criteria. Muscle strength was assessed by grip strength, which was measured by a dynamometer (BASELINE ${ }^{\circledR}$, model 12-0286), and low grip strength was defined as $<28 \mathrm{~kg}$ in men and $<18 \mathrm{~kg}$ in women. Physical performance was assessed by usual gait speed (m/s) on a 6-meter course, and a slow walking speed was defined as slower than 1.0 m/s. Muscle mass was measured by BIA (InBody270). The height-adjusted ASM (ASMI) was defined as appendicular skeletal muscle mass (ASM) divided by height squared. Low muscle mass was defined as ASMI $<7.0 \mathrm{~kg} / \mathrm{m}^{2}$ in men and $<5.7 \mathrm{~kg} / \mathrm{m}^{2}$ in women. The reliability and validity of the tools had been appraised in a systematic review ${ }^{20}$. In a Chinese study involving 944 community-dwelling adults aged $\geq 60$ years ${ }^{21}$, quite high correlation coefficient between the BIA- (InBody720) and DXA-measured ASMs revealed that the tool was suitable for body composition monitoring.

\section{Assessment of physical activity}

PA was assessed using the Taiwan version of IPAQ-S. We have already obtained permission to use the questionnaire. IPAQ-S asks about activities undertaken in leisure time, domestic and gardening (yard), work-related, and transport-related PA in the past seven days. The structured items in the IPAQ-S provide separate scores on walking, moderate-intensity and vigorous-intensity activity.

The intensity of a PA would be expressed in metabolic equivalents (METs). According to the official IPAQ scoring protocol, MET-min per week for an activity were calculated as MET values (vigorous 8.0, moderate 4.0, walking 3.3) x min of activity per day x days per week, and we summed the total PA MET-min/week for each participant ${ }^{22}$. Three levels of PA were used to classify the participants: low, moderate and high.

Since the amount of PA that WHO recommended for older adults equaled to $600 \mathrm{MET}$-min/week, we decided to group PA into two categories: 1. Low PA and 2. Moderate to high PA.

\section{Measurement of demographic factors, clinical factors and comorbidities}

The questions listed in the questionnaire of the health checkup program include sex, age (birthday), current smoking status (Have you smoked in the last half year? (1) Never; (2) Seldom, social smoking; (3) $\leq 1$ pack per day; and (4) > 1 pack per day. Answer 1 was classified as 'No'; other answers were classified as 'Yes'), alcohol drinking (Have you drank alcohol in the last half year? (1) Never; (2) Seldom, social drinking; and (3) Often. Answer 1 was classified as 'No'; other answers were classified as 'Yes'), education levels (We classified the items into 3 categories: (1) $\leq$ elementary school, (2) junior and senior high 
school, and (3) $\geq$ university), history of diseases and so on. If the participants were living in long-term care institutions, we got tabulations from institutions. Body height and body weight were measured and then automatically converted to BMI after recording the data into the system.

The participants' blood samples have been collected during the health exam. We used the results of albumin, uric acid, fasting plasma glucose (FPG), total cholesterol, low-density lipoprotein cholesterol $(\mathrm{LDL}-\mathrm{C})$, high-density lipoprotein cholesterol (HDL-C), triglyceride (TG), and hemoglobin $(\mathrm{Hb})$ as health indices and covariates.

\section{Statistical analyses}

RStudio macOS Version 1.1.456 was used for statistical analysis. SAS 9.4 was used to double check the results. For descriptive statistics, we used $\chi^{2}$ test for categorical variables and $t$ test or Mann-Whitney $U$ test for continuous variables. Multiple logistic regression was used to analyze the relationship between PA and sarcopenia. Two-sided $\mathrm{P}<0.05$ was considered to be statistically significant. We set the level of power at 0.8 and used the software $\mathrm{G}^{*} \mathrm{P}$ ower to calculate the sample size.

Potential associated factors of sarcopenia were specified in the statistical analysis included age, BMI, education level, FPG, serum albumin, uric acid, total cholesterol, LDL-C, HDL-C, TG, Hb, alcohol drinking, smoking, institutionalization, and the history of diabetes mellitus, hypertension, dyslipidemia, cardiovascular disease, and heart disease. We used Akaike's information criterion-based forwardbackward selection for model selection.

\section{Results}

565 participants were recruited, after excluding those refused to participate $(n=12)$ and incomplete or invalid data ones $(n=53)$, data from 500 participants were used for the analysis (Fig. 1). The study participants had a mean age of 73.87 years old, with $47 \%$ men and $53 \%$ women. For both genders, the majority of participants' PA levels were moderate, with women $(142 / 265,53.5 \%)$ and men $(131 / 235$, $55.7 \%$ ). The mean of handgrip was $19.54 \mathrm{~kg}$ in women and $31.43 \mathrm{~kg}$ in men. The mean of usual gait speed was $0.99 \mathrm{~m} / \mathrm{s}$ in women and $1.03 \mathrm{~m} / \mathrm{s}$ in men. The mean of ASMI was $5.75 \mathrm{~kg} / \mathrm{m}^{2}$ in women and $7.20 \mathrm{~kg} / \mathrm{m}^{2}$ in men. We compared the demographic and clinical characteristics between low PA and moderate to high PA groups for all of the participants, which comprised 265 women and 235 men (Table 1 to 2). Due to the limited institutionalized and smoking women, we didn't analysis these two covariates while we did multiple logistic regression.

A total of 138 (27.6\%) participants were classified as having sarcopenia, among whom 87 were women and 51 were men (Table 3). Compared with the low PA group, the OR of moderate to high PA to sarcopenia was $0.52(95 \% \mathrm{Cl}: 0.27-0.98, \mathrm{p}$-value $=0.043)$ in women, after adjusting for age, $\mathrm{BMI}$, and albumin and hemoglobin levels. As for men, compared with the low PA group, the OR of moderate to high PA to sarcopenia was $0.34(95 \% \mathrm{Cl}$ : $0.12-0.95$, p-value $=0.039)$, after adjusting for age, BMI, history of cardiovascular disease, history of heart disease and institutionalization (Table 4). 


\section{Discussion}

In this study, we observed that a significant protective effect of PA on sarcopenia was found among the older adults after adjusting for confounders for both genders. The prevalence of sarcopenia in this study population and our main findings were similar to most cross-sectional studies [5]. The prevalence was higher in women $(32.8 \%)$ than men $(21.7 \%)$. The relationship between PA, aging, BMI and sarcopenia were consistent with most of previous studies [19]. Furthermore, a stronger protective effect of PA on the male participants was noted, whereas higher BMI showed a protective effect on sarcopenia in both genders. Additionally, our results also showed that aging was a risk factor of sarcopenia.

Body muscle mass and strength are different in men and women (men greater than women) by nature. Besides, it is speculated that gender-related difference in regulation of muscle contraction may result in the more obvious frailty and impairment of muscle function in old women than in old men ${ }^{23}$. Further, in a survey of 2,264 older Korean adults, there were gender differences in the relationship between PA and sarcopenia, with stronger associations observed in men ${ }^{24}$. Hence, we analyzed both genders dividedly.

We tried to search similar cross-sectional studies using structural questionnaires to evaluate PA and both of muscle mass and function to diagnose sarcopenia. Compare to previous Asian studies, one China study showed PA was not related to sarcopenia, but this study analyzed both genders together ${ }^{25}$. In one Korean study, vigorous and moderate PA were not associated with sarcopenia, but if PA displayed in quantiles, the third and fourth quantiles PA of the subjects showed protect effect on sarcopenia in Korean men ${ }^{26}$. As for the gender differences, our study showed PA was a protective factor of sarcopenia and more obvious in men while one Korean study showed the relationship between PA and sarcopenia was significant statistically in men but not in women ${ }^{24}$. On the other hand, in the western countries, one study in Peruvian Andes found that age, female sex, a low BMI, and little PA were associated factors of sarcopenia ${ }^{27}$. However, an Italian study showed nutritional intake, PA, and level of comorbidity were not associated with sarcopenia ${ }^{28}$. Nevertheless, a multi-continent study enrolled 18363 people showed PA was a key factor for the prevention of sarcopenia ${ }^{29}$.

Although aging is the main cause of sarcopenia, it is an inevitable process. Since we can see the obvious protective effect of PA on sarcopenia, we should advocate regular physical activity to the public. Our study is unique in that we classified the PA according to WHO's recommendation. Although previous researchers might explore the association between PA and sarcopenia via IPAQ, they classified the PA just according to the IPAQ protocol (into low, moderate and high), or by vigorous PA, moderate PA, and walking PA, or by quantiles ${ }^{26}$. Indeed, for additional benefits, older adults should increase their PA. However, in our daily clinical practice or health promotion activities, we found that when we tried to educate the older adults to do physical activity, some of them might refuse and mentioned that it was impossible for them to do 'exercise'. Besides, some experts doubt that the PA level of at least 600 METmin per week is enough. However, in our findings, the global recommendation of PA already showed obvious benefit to the older adults in the prevalence of sarcopenia. Through this study, we can apply our 
findings as an echo of WHO's recommendation to educate the public that older adults can accumulate PA in their daily, family and community lives.

The moderate to high PA group was composed of higher education level of male participants. However, the effect of education level on sarcopenia was not statistically significant in this study after we adjusted covariates. Although some studies showed the effect of education level on sarcopenia ${ }^{28}$, there is much more health-related knowledge spreading through social media and community care centers than before, so the health literacy may be elevated in the older adults regardless of their educational levels.

Sarcopenia prevalence are usually higher in long-term care institutions. Besides, most of the residents may have several chronic diseases and comorbidities, who may have less PA compare to those living at homes. Hence, we expected to explore the association between institutionalization and sarcopenia based on the premise that confounders were adjusted. However, due to we only collected 4 women living in longterm care institutions, we did not analyze this relationship. As for the men, the OR of institutionalization to sarcopenia was 2.94 (95\% Cl: $0.97-8.90)$ despite this result was not significant statistically ( $p$-value = 0.057). Although living in long-term care institutions similarly, those who can attend the health checkup program may be healthier compared to those who cannot or refuse to do so. Suppose we collect more institutionalized people, the association between institutionalization and sarcopenia may be clearer.

Metabolites, such as reactive oxygen species, reactive nitrogen species, and aldehydes are components of the cigarettes smoke, enter the bloodstream and arrive at the skeletal muscles of smokers and accelerate muscle wasting ${ }^{30}$. Based on the theory above, we assumed there should be association between smoking and sarcopenia. However, only one woman in this group was a smoker so we did not analyze the relationship. In the traditional Chinese society, it brought about a negative concept that a woman was a smoker. Consequently, some people might pretend that they were not smokers, which was one kind of social desirability bias. Moreover, the Taiwanese older generation didn't have smoking habit originally, which reflected on that smoking rate was low ( $0.7 \%$ in women) in adults above 65 years old according to the 2018 Adult Smoking Behavior Surveillance System. It was reasonably that we only recruited one smoking woman.

With increased lean body mass loss, associated mortality increased, which even could up to $100 \%$ when one person has lost $40 \%$ lean body mass [3]. One previous study showed increased sarcopenia prevalence with decreased $\mathrm{BMI}^{31}$. The association between $\mathrm{BMI}$ and mortality has been revealed to have a U- or J-shaped configuration, with better health-related outcomes and longevity observed for older adults in the overweight category of the BMI classification ${ }^{32}$. In the past, the traditional concept has been that being thin leads to longevity. Nowadays, more and more geriatricians and dietitians are saying that extremely low BMI is related to higher mortality. Our study proved that higher BMI was a protective factor of sarcopenia. Hence, we can do some education to the underweight older adults, encouraging them to keep a suitable weight for better health. 
One of the strengths of our study was including demographic and clinical factors. Additionally, our study consisted of international physical activity and sarcopenia assessment tools, which can be compared with other countries. To our best knowledge, this is the first Taiwanese data using the latest AWGS diagnostic criteria to analyze the participants. We can use the result to appeal to the health care professionals to pay attention to the increasing sarcopenia population.

Our study had several limitations. First of all, it was a cross-sectional study which only revealed the association between PA and sarcopenia, but not illustrating the cause-effect relationship. In addition, the participants were recruited during the health exam and there might be a selection or sampling bias due to healthy user effect. Since this was a hospital-based study, rather than a community-based study, we just did convenience sampling. Hence, we could not collect enough institutionalized women. Besides, there was just one woman had smoking habit. Therefore, we could not explore the relationship between institutionalization and sarcopenia, and smoking and sarcopenia in women group. The participation bias might exist and thus the results cannot be extrapolated to the general population.

\section{Conclusions}

A significant protective effect of physical activity on sarcopenia was found among the older adults after adjusting for confounders, especially for the male participants. Higher BMI showed protective effect on sarcopenia, while aging was a risk factor of sarcopenia. Further cohort studies and even RCTs may be needed to confirm our findings.

\section{Declarations}

\section{Competing interests}

The authors declare no competing interests

\section{Authors' contributions}

Y.C. collected, analyzed and interpreted the data, and was a major contributor in writing the manuscript. Y.C. and W.C. conducted the statistical analysis. Y.C., T.Y. and W.C. contributed to the design of the study. Y.C., C.Y., and W.R. contributed to the data collection. W.R. contributed to the conceptualization of the manuscript. All authors provided feedback during manuscript development and approved the final manuscript.

\section{Data availability}

The datasets generated and/or analyzed during the current study are not publicly available due to legal restrictions imposed by the government of Taiwan in relation to the "Personal Information Protection Act". 


\section{References}

1. Bischoff-Ferrari, H. A. et al. Comparative performance of current definitions of sarcopenia against the prospective incidence of falls among community-dwelling seniors age 65 and older. Osteoporos Int 26, 2793-2802, doi:10.1007/s00198-015-3194-y (2015).

2. De Buyser, S. L. et al. Validation of the FNIH sarcopenia criteria and SOF frailty index as predictors of long-term mortality in ambulatory older men. Age Ageing 45, 602-608, doi:10.1093/ageing/afw071 (2016).

3. Demling, R. H. Nutrition, anabolism, and the wound healing process: an overview. Eplasty 9, e9 (2009).

4. Vellas, B. et al. Implications of ICD-10 for Sarcopenia Clinical Practice and Clinical Trials: Report by the International Conference on Frailty and Sarcopenia Research Task Force. J Frailty Aging 7, 2-9, doi:10.14283/jfa.2017.30 (2018).

5. Mayhew, A. J. et al. The prevalence of sarcopenia in community-dwelling older adults, an exploration of differences between studies and within definitions: a systematic review and meta-analyses. Age Ageing 48, 48-56, doi:10.1093/ageing/afy106 (2019).

6. Chen, L. K. et al. Sarcopenia in Asia: consensus report of the Asian Working Group for Sarcopenia. J Am Med Dir Assoc 15, 95-101, doi:10.1016/j.jamda.2013.11.025 (2014).

7. Chen, L. K. et al. Asian Working Group for Sarcopenia: 2019 Consensus Update on Sarcopenia Diagnosis and Treatment. J Am Med Dir Assoc 21, 300-307 e302, doi:10.1016/j.jamda.2019.12.012 (2020).

8. Leon, A. S. Attenuation of Adverse Effects of Aging on Skeletal Muscle by Regular Exercise and Nutritional Support. Am J Lifestyle Med 11, 4-16, doi:10.1177/1559827615589319 (2017).

9. Beaudart, C. et al. Nutrition and physical activity in the prevention and treatment of sarcopenia: systematic review. Osteoporos Int 28, 1817-1833, doi:10.1007/s00198-017-3980-9 (2017).

10. Mijnarends, D. M. et al. Physical activity and incidence of sarcopenia: the population-based AGESReykjavik Study. Age Ageing 45, 614-620, doi:10.1093/ageing/afw090 (2016).

11. World health organization. Physical activity. https://www.who.int/health-topics/physical-activity Accessed 10 Feb 2020.

12. World Health Organization. Global health risks : mortality and burden of disease attributable to selected major risks. World Health Organization; 2009.

13. World Health Organization. Global recommendations on physical activity for health (65 years and above). https://www.who.int/dietphysicalactivity/physical-activity-recommendations-65years.pdf Accessed 10 Feb 2020.

14. Dowd, K. P. et al. A systematic literature review of reviews on techniques for physical activity measurement in adults: a DEDIPAC study. Int J Behav Nutr Phys Act 15, 15, doi:10.1186/s12966-0170636-2 (2018). 
15. Steene-Johannessen, J. et al. Are Self-report Measures Able to Define Individuals as Physically Active or Inactive? Med Sci Sports Exerc 48, 235-244, doi:10.1249/MSS.0000000000000760 (2016).

16. Sylvia, L. G., Bernstein, E. E., Hubbard, J. L., Keating, L. \& Anderson, E. J. Practical guide to measuring physical activity. J Acad Nutr Diet 114, 199-208, doi:10.1016/j.jand.2013.09.018 (2014).

17. Liou YM, Development and Verification of Validity and Reliability of the International Physical Activity Questionnaire Taiwan Version. 2004; doi:10.6342/NTU.2004.02074

18. Liou, Y. M., Jwo, C. J., Yao, K. G., Chiang, L. C. \& Huang, L. H. Selection of appropriate Chinese terms to represent intensity and types of physical activity terms for use in the Taiwan version of IPAQ. $J$ Nurs Res 16, 252-263, doi:10.1097/01.jnr.0000387313.20386.0a (2008).

19. Steffl, M. et al. Relationship between sarcopenia and physical activity in older people: a systematic review and meta-analysis. Clin Interv Aging 12, 835-845, doi:10.2147/CIA.S132940 (2017).

20. Mijnarends, D. M. et al. Validity and reliability of tools to measure muscle mass, strength, and physical performance in community-dwelling older people: a systematic review. J Am Med Dir Assoc 14, 170-178, doi:10.1016/j.jamda.2012.10.009 (2013).

21. Wang, H. et al. Estimation of prevalence of sarcopenia by using a new bioelectrical impedance analysis in Chinese community-dwelling elderly people. BMC Geriatr 16, 216, doi:10.1186/s12877016-0386-z (2016).

22. Emma Patterson, Guidelines for Data Processing and Analysis of the International PhysicalActivity. Questionnaire (IPAQ) - Short and Long Forms, 2005 Nov

23. Yu, F., Hedstrom, M., Cristea, A., Dalen, N. \& Larsson, L. Effects of ageing and gender on contractile properties in human skeletal muscle and single fibres. Acta Physiol (Oxf) 190, 229-241, doi:10.1111/j.1748-1716.2007.01699.x (2007).

24. Ryu, M. et al. Association of physical activity with sarcopenia and sarcopenic obesity in communitydwelling older adults: the Fourth Korea National Health and Nutrition Examination Survey. Age Ageing 42, 734-740, doi:10.1093/ageing/aft063 (2013).

25. Hai, S. et al. Association between sarcopenia with lifestyle and family function among communitydwelling Chinese aged 60 years and older. BMC Geriatr 17, 187, doi:10.1186/s12877-017-0587-0 (2017).

26. Kim, S. H., Kim, T. H. \& Hwang, H. J. The relationship of physical activity (PA) and walking with sarcopenia in Korean males aged 60 years and older using the Fourth Korean National Health and Nutrition Examination Survey (KNHANES IV-2,3), 2008-2009. Archives of gerontology and geriatrics 56, 472-477, doi:10.1016/j.archger.2012.12.009 (2013).

27. Tramontano, A. et al. Prevalence of sarcopenia and associated factors in the healthy older adults of the Peruvian Andes. Archives of gerontology and geriatrics 68, 49-54, doi:10.1016/j.archger.2016.09.002 (2017).

28. Volpato, S. et al. Prevalence and clinical correlates of sarcopenia in community-dwelling older people: application of the EWGSOP definition and diagnostic algorithm. J Gerontol A Biol Sci Med Sci 69, 438-446, doi:10.1093/gerona/glt149 (2014). 
29. Tyrovolas, S. et al. Factors associated with skeletal muscle mass, sarcopenia, and sarcopenic obesity in older adults: a multi-continent study. J Cachexia Sarcopenia Muscle 7, 312-321, doi:10.1002/jcsm.12076 (2016).

30. Rom, O., Kaisari, S., Aizenbud, D. \& Reznick, A. Z. Sarcopenia and smoking: a possible cellular model of cigarette smoke effects on muscle protein breakdown. Ann N Y Acad Sci 1259, 47-53, doi:10.1111/j.1749-6632.2012.06532.x (2012).

31. Linge, J., Heymsfield, S. B. \& Dahlqvist Leinhard, O. On the Definition of Sarcopenia in the Presence of Aging and Obesity-Initial Results from UK Biobank. J Gerontol A Biol Sci Med Sci 75, 1309-1316, doi:10.1093/gerona/glz229 (2020).

32. Flicker, L. et al. Body mass index and survival in men and women aged 70 to 75. J Am Geriatr Soc 58, 234-241, doi:10.1111/j.1532-5415.2009.02677.x (2010).

\section{Tables}


Table 1

Basic demographic and clinical characteristics of the study participants

\begin{tabular}{|c|c|c|c|}
\hline & $\begin{array}{l}\text { Low PA } \\
(n=106)\end{array}$ & $\begin{array}{l}\text { Moderate to High PA* } \\
(n=394)\end{array}$ & P-value \\
\hline Sarcopenia & & & $<0.0001$ \\
\hline $\mathrm{N}$ & $58(54.7 \%)$ & $304(77.2 \%)$ & \\
\hline Y & $48(45.3 \%)$ & $90(22.8 \%)$ & \\
\hline \multicolumn{4}{|l|}{ Age, years } \\
\hline Mean (SD) & $75.0(6.79)$ & $73.6(6.62)$ & 0.045 \\
\hline Median [Min, Max] & $74.0[65.0,91.0]$ & $72.0[63.0,97.0]$ & 0.039 \\
\hline Gender, n (\%) & & & 0.0003 \\
\hline Women & $73(68.9 \%)$ & 192(48.7\%) & \\
\hline Men & $33(31.1 \%)$ & $202(51.3 \%)$ & \\
\hline \multicolumn{4}{|l|}{ BMI } \\
\hline Mean (SD) & $23.5(3.31)$ & $23.9(3.22)$ & 0.259 \\
\hline Median [Min, Max] & $23.2[14.6,32.8]$ & $23.6[16.2,40.5]$ & 0.301 \\
\hline Institutionalization & & & 0.0002 \\
\hline$N$ & $91(85.8 \%)$ & $379(96.2 \%)$ & \\
\hline Y & $15(14.2 \%)$ & $15(3.8 \%)$ & \\
\hline Alcohol drinking & & & 0.020 \\
\hline $\mathrm{N}$ & $97(91.5 \%)$ & $321(81.5 \%)$ & \\
\hline Y & $9(8.5 \%)$ & 73(18.5\%) & \\
\hline Smoking & & & 1.000 \\
\hline $\mathrm{N}$ & 100(94.3\%) & $374(94.9 \%)$ & \\
\hline Y & $6(5.7 \%)$ & $20(5.1 \%)$ & \\
\hline Education level & & & 0.003 \\
\hline $1 \leq$ elementary school & $39(36.8 \%)$ & $88(22.3 \%)$ & \\
\hline 2 Junior/senior high school & $23(21.7 \%)$ & $138(35.0 \%)$ & \\
\hline $3 \geq$ University & $44(41.5 \%)$ & $268(68.0 \%)$ & \\
\hline Past history & & & \\
\hline
\end{tabular}




\begin{tabular}{|c|c|c|c|}
\hline & $\begin{array}{l}\text { Low PA } \\
(n=106)\end{array}$ & $\begin{array}{l}\text { Moderate to High PA* } \\
(n=394)\end{array}$ & P-value \\
\hline Hypertension & $43(40.1 \%)$ & $138(35 \%)$ & 0.347 \\
\hline Diabetes Mellitus & $14(13.2 \%)$ & $56(14.2 \%)$ & 0.915 \\
\hline Hyperlipidemia & $24(22.6 \%)$ & $78(19.8 \%)$ & 0.611 \\
\hline Cardiovascular disease & $10(9.4 \%)$ & $36(9.1 \%)$ & 1.000 \\
\hline Heart disease & $18(17.0 \%)$ & $35(8.9 \%)$ & 0.026 \\
\hline \multicolumn{4}{|l|}{ Albumin, $\mathrm{g} / \mathrm{dL}$} \\
\hline Mean (SD) & $4.39(0.231)$ & $4.40(0.243)$ & 0.716 \\
\hline Median [Min, Max] & $4.40[3.70,4.90]$ & $4.40[3.00,5.10]$ & 0.795 \\
\hline \multicolumn{4}{|l|}{ Uric acid, $\mathrm{mg} / \mathrm{dL}$} \\
\hline Mean (SD) & $5.37(1.30)$ & $5.55(1.40)$ & 0.244 \\
\hline Median [Min, Max] & $5.30[2.50,8.80]$ & $5.50[2.50,12.3]$ & 0.332 \\
\hline \multicolumn{4}{|l|}{ Total Cholesterol, mg/dL } \\
\hline Mean (SD) & $179(33.0)$ & $181(31.5)$ & 0.517 \\
\hline Median [Min, Max] & $176[115,254]$ & $179[106,277]$ & 0.401 \\
\hline \multicolumn{4}{|l|}{$\mathrm{AC}$ sugar, $\mathrm{mg} / \mathrm{dL}$} \\
\hline Mean (SD) & $103(21.7)$ & $103(20.8)$ & 0.885 \\
\hline Median [Min, Max] & $98.0[77.0,214]$ & $99.0[75.0,232]$ & 0.931 \\
\hline \multicolumn{4}{|l|}{ LDL, mg/dL } \\
\hline Mean (SD) & $102(28.9)$ & $103(27.8)$ & 0.610 \\
\hline Median [Min, Max] & $98.5[46.0,166]$ & $102[28.0,183]$ & 0.442 \\
\hline \multicolumn{4}{|l|}{$\mathrm{HDL}, \mathrm{mg} / \mathrm{dL}$} \\
\hline Mean (SD) & $55.3(12.7)$ & $55.9(14.3)$ & 0.711 \\
\hline Median [Min, Max] & $54.5[26.0,92.0]$ & $53.0[27.0,108]$ & 0.996 \\
\hline \multicolumn{4}{|l|}{$\mathrm{TG}, \mathrm{mg} / \mathrm{dL}$} \\
\hline Mean (SD) & $108.4(49.6)$ & $109.3(50.6)$ & 0.912 \\
\hline Median [Min, Max] & $101[38.0,268]$ & $101[29.0,372]$ & 0.926 \\
\hline
\end{tabular}




\begin{tabular}{|llll|}
\hline & $\begin{array}{l}\text { Low PA } \\
(\mathbf{n = 1 0 6 )}\end{array}$ & $\begin{array}{l}\text { Moderate to High PA* } \\
(\mathbf{n}=\mathbf{3 9 4})\end{array}$ & P-value \\
\hline Mean (SD) & $13.2(1.21)$ & $13.5(1.35)$ & 0.026 \\
\hline Median [Min, Max] & $13.2[10.1,16.2]$ & $13.6[9.10,17.9]$ & 0.017 \\
\hline *Physical activity level according to IPAQ category & \\
\hline
\end{tabular}


Table 2

Basic demographic and clinical characteristics of the study participants by gender

\begin{tabular}{|c|c|c|c|c|c|c|}
\hline & \multicolumn{3}{|l|}{$\begin{array}{l}\text { Women (n } \\
=265)\end{array}$} & \multicolumn{3}{|c|}{ Men $(n=235)$} \\
\hline & $\begin{array}{l}\text { Low PA } \\
(n=73 \text {, } \\
27.5 \%)\end{array}$ & $\begin{array}{l}\text { Moderate to } \\
\text { High PA* } \\
(\mathrm{n}=192, \\
72.5 \%)\end{array}$ & $\begin{array}{l}\text { P- } \\
\text { value }\end{array}$ & $\begin{array}{l}\text { Low PA } \\
(n=33 \text {, } \\
14.0 \%)\end{array}$ & $\begin{array}{l}\text { Moderate to } \\
\text { High PA* } \\
(n=202 \\
86.0 \%)\end{array}$ & $\begin{array}{l}\mathrm{P}- \\
\text { value }\end{array}$ \\
\hline $\begin{array}{l}\text { Sarcopenia by } \\
2019 \text { AWGS }\end{array}$ & & & 0.003 & & & 0.002 \\
\hline$N$ & $39(53.4 \%)$ & $139(72.4 \%)$ & & $\begin{array}{l}19 \\
(57.6 \%)\end{array}$ & 165 (81.7\%) & \\
\hline Y & $34(46.6 \%)$ & $53(27.6 \%)$ & & $\begin{array}{l}14 \\
(42.4 \%)\end{array}$ & 37 (18.3\%) & \\
\hline \multicolumn{7}{|l|}{ Age, years } \\
\hline Mean (SD) & $74.3(6.98)$ & $72.8(6.37)$ & 0.090 & $\begin{array}{l}76.5 \\
(6.18)\end{array}$ & $74.3(6.79)$ & 0.073 \\
\hline Median [Min, Max] & $\begin{array}{l}74.0[65.0, \\
91.0]\end{array}$ & $\begin{array}{l}71.0[63.0, \\
91.0]\end{array}$ & 0.123 & $\begin{array}{l}79.0 \\
{[65.0,} \\
88.0]\end{array}$ & $\begin{array}{l}73.0[65.0, \\
97.0]\end{array}$ & 0.036 \\
\hline \multicolumn{7}{|l|}{ BMI } \\
\hline Mean (SD) & $23.1(3.35)$ & $23.7(3.32)$ & 0.217 & $\begin{array}{l}24.2 \\
(3.15)\end{array}$ & $24.0(3.12)$ & 0.754 \\
\hline Median [Min, Max] & $\begin{array}{l}22.9[14.6, \\
32.8]\end{array}$ & $\begin{array}{l}23.4[16.2, \\
35.9]\end{array}$ & 0.182 & $\begin{array}{l}24.1 \\
{[17.2,} \\
30.3]\end{array}$ & $\begin{array}{l}23.8[17.1 \\
40.5]\end{array}$ & 0.467 \\
\hline Institutionalization & & & $0.305^{\#}$ & & & $\begin{array}{l}< \\
0.001^{\#}\end{array}$ \\
\hline$N$ & $71(97.3 \%)$ & $190(99.0 \%)$ & & $\begin{array}{l}20 \\
(60.6 \%)\end{array}$ & $189(93.6 \%)$ & \\
\hline Y & $2(2.7 \%)$ & $2(1 \%)$ & & $\begin{array}{l}13 \\
(39.4 \%)\end{array}$ & $13(6.4 \%)$ & \\
\hline Alcohol drinking & & & 0.690 & & & 0.051 \\
\hline N & 68 (93.1\%) & 176 (91.7\%) & & $\begin{array}{l}29 \\
(87.9 \%)\end{array}$ & 145 (71.8\%) & \\
\hline Y & $5(6.9 \%)$ & $16(8.3 \%)$ & & $4(12.1 \%)$ & 57 (28.2\%) & \\
\hline Education level & & & 0.223 & & & 0.001 \\
\hline
\end{tabular}




\begin{tabular}{|c|c|c|c|c|c|c|}
\hline \multirow[b]{2}{*}{$\begin{array}{l}1 \leq \text { Elementary } \\
\text { school }\end{array}$} & \multicolumn{3}{|l|}{$\begin{array}{l}\text { Women (n } \\
=265)\end{array}$} & \multicolumn{3}{|c|}{ Men $(n=235)$} \\
\hline & 24 (32.9\%) & $50(26.0 \%)$ & & $\begin{array}{l}15 \\
(45.5 \%)\end{array}$ & 38 (18.8\%) & \\
\hline $\begin{array}{l}2 \text { Junior/senior } \\
\text { high school }\end{array}$ & 20 (27.4\%) & 74 (38.5\%) & & $3(9.1 \%)$ & 64 (31.7\%) & \\
\hline $3 \geq$ University & 29 (39.7\%) & 68 (35.4\%) & & $\begin{array}{l}15 \\
(45.5 \%)\end{array}$ & $100(49.5 \%)$ & \\
\hline \multicolumn{7}{|l|}{ Medical history } \\
\hline Hypertension & 28 (38.4\%) & 66 (34.4\%) & 0.545 & $\begin{array}{l}15 \\
(45.5 \%)\end{array}$ & 72 (35.6\%) & 0.279 \\
\hline Diabetes mellitus & 10 (13.7\%) & 25 (13.0\%) & 0.884 & $4(12.1 \%)$ & $31(15.3 \%)$ & $0.753^{\#}$ \\
\hline Hyperlipidemia & $21(28.8 \%)$ & 45 (23.4\%) & 0.370 & $3(9.1 \%)$ & 33 (16.3\%) & 0.284 \\
\hline $\begin{array}{l}\text { Cardiovascular } \\
\text { disease }\end{array}$ & $4(5.48 \%)$ & $12(6.25 \%)$ & $1.000^{\#}$ & $6(18.2 \%)$ & 24 (11.9\%) & 0.395 \\
\hline Heart disease & $13(17.8 \%)$ & $16(8.33 \%)$ & 0.027 & $5(15.2 \%)$ & 19 (9.41\%) & $0.349^{\#}$ \\
\hline
\end{tabular}


Table 2

Basic demographic and clinical characteristics of the study participants by gender (Continued)

\section{Women ( $\mathrm{n}$ \\ $=265)$ \\ Men ( $n=235)$}

$\begin{array}{llllll}\text { Low PA } & \begin{array}{l}\text { Moderate to } \\ \text { High PA* }\end{array} & \begin{array}{l}\text { P- } \\ \text { value }\end{array} & \begin{array}{l}\text { Low PA } \\ (n=33,\end{array} & \begin{array}{l}\text { Moderate to } \\ \text { High PA* }\end{array} & \begin{array}{l}\text { P- } \\ \text { value }\end{array} \\ 27.5 \%) & (n=192, & & 14.0 \%) & (n=202, & \\ & 72.5 \%) & & & 86.0 \%) & \end{array}$

Albumin, $\mathrm{g} / \mathrm{dL}$

$\begin{array}{lllllll}\text { Mean (SD) } & \begin{array}{l}4.39 \\ (0.231)\end{array} & 4.40(0.243) & 0.716 & \begin{array}{l}4.32 \\ (0.268)\end{array} & 4.39(0.232) & 0.141 \\ & & & & \\ \text { Median [Min, } & 4.40[3.70, & 4.40[3.00, & 0.795 & \begin{array}{l}4.30 \\ {[3.90,}\end{array} & 4.40[3.00, & 0.113 \\ \text { Max] } & 4.90] & 5.10] & & \begin{array}{l}5.00] \\ 4.90]\end{array} & \end{array}$

Uric acid, $\mathrm{mg} / \mathrm{dL}$

$\begin{array}{lllllll}\text { Mean (SD) } & 5.37(1.30) & 5.55(1.40) & 0.244 & \begin{array}{l}6.05 \\ (1.54)\end{array} & 6.04(1.37) & 0.985 \\ & & & & & \\ \text { Median [Min, } & 5.30[2.50, & 5.50[2.50, & 0.332 & \begin{array}{l}6.20 \\ {[2.50,}\end{array} & 5.90[2.50, & 0.630 \\ \text { Max] } & 8.80] & 12.3] & & 8.80] & & \end{array}$

Total

Cholesterol,

$\mathrm{mg} / \mathrm{dL}$

$\begin{array}{lllllll}\text { Mean (SD) } & 179(33.0) & 181(31.5) & 0.517 & \begin{array}{l}167 \\ (34.6)\end{array} & 173(29.4) & 0.275\end{array}$

\begin{tabular}{|c|}
\hline $\begin{array}{l}\text { Median [Min, } \\
\text { Max] }\end{array}$ \\
\hline
\end{tabular}

FPG, $\mathrm{mg} / \mathrm{dL}$

\begin{tabular}{|c|c|c|c|c|c|c|}
\hline Mean (SD) & 103 (21.7) & $103(20.8)$ & 0.885 & $\begin{array}{l}103 \\
(20.1)\end{array}$ & $104(20.0)$ & 0.784 \\
\hline $\begin{array}{l}\text { Median [Min, } \\
\text { Max] }\end{array}$ & $\begin{array}{l}98.0[77.0, \\
214]\end{array}$ & $\begin{array}{l}99.0 \text { [75.0, } \\
232]\end{array}$ & 0.931 & $\begin{array}{l}100[77.0 \\
183]\end{array}$ & $\begin{array}{l}99.5 \text { [75.0, } \\
231]\end{array}$ & 0.877 \\
\hline \multicolumn{7}{|l|}{ LDL-C, mg/dL } \\
\hline Mean (SD) & $102(28.9)$ & $103(27.8)$ & 0.610 & $\begin{array}{l}96.7 \\
(30.8)\end{array}$ & $100(26.5)$ & 0.468 \\
\hline $\begin{array}{l}\text { Median [Min, } \\
\text { Max] }\end{array}$ & $\begin{array}{l}98.5[46.0, \\
166]\end{array}$ & $102[28.0,183]$ & 0.442 & $\begin{array}{l}87.0 \\
{[46.0} \\
153]\end{array}$ & $\begin{array}{l}99.0 \text { [48.0, } \\
181]\end{array}$ & 0.338 \\
\hline
\end{tabular}

HDL-C, mg/dL 


\begin{tabular}{|c|c|c|c|c|c|c|}
\hline \multirow[b]{2}{*}{ Mean (SD) } & \multicolumn{3}{|l|}{$\begin{array}{l}\text { Women (n } \\
=265)\end{array}$} & \multicolumn{3}{|c|}{ Men $(n=235)$} \\
\hline & $55.3(12.7)$ & $55.9(14.3)$ & 0.711 & $\begin{array}{l}50.6 \\
(11.2)\end{array}$ & $51.9(12.6)$ & 0.579 \\
\hline $\begin{array}{l}\text { Median [Min, } \\
\text { Max] }\end{array}$ & $\begin{array}{l}54.5[26.0, \\
92.0]\end{array}$ & $\begin{array}{l}53.0[27.0, \\
108]\end{array}$ & 0.996 & $\begin{array}{l}50.0 \\
{[26.0,} \\
72.0]\end{array}$ & $\begin{array}{l}51.0[27.0, \\
89.0]\end{array}$ & 0.833 \\
\hline \multicolumn{7}{|l|}{$\mathrm{TG}, \mathrm{mg} / \mathrm{dL}$} \\
\hline Mean (SD) & $\begin{array}{l}108.4 \\
(49.6)\end{array}$ & $109.3(50.6)$ & 0.912 & $\begin{array}{l}98.3 \\
(47.2)\end{array}$ & 104 (49.6) & 0.536 \\
\hline $\begin{array}{l}\text { Median [Min, } \\
\text { Max] }\end{array}$ & $\begin{array}{l}101[38.0, \\
268]\end{array}$ & $101[29.0,372]$ & 0.926 & $\begin{array}{l}90.0 \\
{[38.0} \\
262]\end{array}$ & $\begin{array}{l}95.0[29.0 \\
372]\end{array}$ & 0.460 \\
\hline \multicolumn{7}{|l|}{$\begin{array}{l}\text { Hemoglobin, } \\
\mathrm{g} / \mathrm{dL}\end{array}$} \\
\hline Mean (SD) & $13.2(1.21)$ & 13.5 (1.35) & 0.026 & $\begin{array}{l}13.3 \\
(1.49)\end{array}$ & $14.0(1.32)$ & 0.006 \\
\hline $\begin{array}{l}\text { Median [Min, } \\
\text { Max] }\end{array}$ & $\begin{array}{l}13.2[10.1 \\
16.2]\end{array}$ & $\begin{array}{l}\text { 13.6 [9.10, } \\
17.9]\end{array}$ & 0.017 & $\begin{array}{l}13.4 \\
{[10.1} \\
16.2]\end{array}$ & $\begin{array}{l}14.0[9.10 \\
17.9]\end{array}$ & 0.014 \\
\hline Smoking & & & $1.000^{\#}$ & & & $0.134^{\#}$ \\
\hline$N$ & 73 (100\%) & 191 (99.5\%) & & $\begin{array}{l}27 \\
(81.8 \%)\end{array}$ & $183(90.6 \%)$ & \\
\hline Y & $0(0 \%)$ & $1(0.05 \%)$ & & $6(18.2 \%)$ & 19 (9.4\%) & \\
\hline \multicolumn{7}{|c|}{ *Physical activity level according to IPAQ category \#Fisher's exact test } \\
\hline $\begin{array}{l}\text { FPG, fasting } \\
\text { lipoprotein } \mathrm{ch}\end{array}$ & lucose; LL & low-density lip & rotein & lesterol; HI & -C, high-densit & \\
\hline
\end{tabular}


Table 3

Comparisons of covariates in non-sarcopenia and sarcopenia participants according to the 2019 AWGS diagnostic criteria of sarcopenia

\begin{tabular}{|c|c|c|c|c|c|c|}
\hline & \multicolumn{3}{|c|}{ Women $(n=265)$} & \multicolumn{3}{|l|}{ Men $(n=235)$} \\
\hline & $\begin{array}{l}\text { Non- } \\
\text { Sarcopenia (N } \\
=178)\end{array}$ & $\begin{array}{l}\text { Sarcopenia } \\
(\mathrm{N}=87)\end{array}$ & $\begin{array}{l}\mathrm{P} \text { - } \\
\text { value }\end{array}$ & $\begin{array}{l}\text { Non- } \\
\text { Sarcopenia (N } \\
=184)\end{array}$ & $\begin{array}{l}\text { Sarcopenia } \\
(N=51)\end{array}$ & $\begin{array}{l}\mathrm{P} \text { - } \\
\text { value }\end{array}$ \\
\hline Physical activity & & & 0.005 & & & 0.004 \\
\hline Low & $39(53.4 \%)$ & $34(46.6 \%)$ & & $19(57.6 \%)$ & $14(42.4 \%)$ & \\
\hline $\begin{array}{l}\text { Moderate to } \\
\text { high }\end{array}$ & $139(72.4 \%)$ & $53(27.6 \%)$ & & $165(81.7 \%)$ & $37(18.3 \%)$ & \\
\hline Institutionalization & & & 0.203 & & & 0.001 \\
\hline No & $177(67.8 \%)$ & $84(32.2 \%)$ & & $171(81.8 \%)$ & $38(18.2 \%)$ & \\
\hline Yes & $1(100.0 \%)$ & $3(0.0 \%)$ & & $13(50.0 \%)$ & $13(50.0 \%)$ & \\
\hline Alcohol drinking & & & 0.500 & & & 0.087 \\
\hline No & $162(66.4 \%)$ & $82(33.6 \%)$ & & $131(75.3 \%)$ & $43(24.7 \%)$ & \\
\hline Yes & $16(76.2 \%)$ & $5(23.8 \%)$ & & $53(86.9 \%)$ & $8(13.1 \%)$ & \\
\hline Smoking & & & 1.000 & & & 0.970 \\
\hline No & $177(67.1 \%)$ & 87 (32.9\%) & & $165(78.6 \%)$ & $45(21.4 \%)$ & \\
\hline Yes & $1(100.0 \%)$ & $0(0.0 \%)$ & & $19(76.0 \%)$ & $6(24.0 \%)$ & \\
\hline Education level & & & 0.205 & & & 0.044 \\
\hline $\begin{array}{l}\text { SElementary } \\
\text { school }\end{array}$ & $44(59.5 \%)$ & $30(40.5 \%)$ & & $35(66.0 \%)$ & $18(34.0 \%)$ & \\
\hline $\begin{array}{l}\text { Junior/senior } \\
\text { high school }\end{array}$ & $68(72.3 \%)$ & $26(27.7 \%)$ & & $56(83.6 \%)$ & $11(16.4 \%)$ & \\
\hline$\geq$ University & $66(68.0 \%)$ & $31(32.0 \%)$ & & $93(80.9 \%)$ & $22(19.1 \%)$ & \\
\hline
\end{tabular}


Table 3

Comparisons of covariates in non-sarcopenia and sarcopenia participants according to the 2019 AWGS diagnostic criteria of sarcopenia (Continued)

\begin{tabular}{|c|c|c|c|c|c|c|}
\hline & $\begin{array}{l}\text { Women }(n= \\
265)\end{array}$ & & & $\begin{array}{l}\text { Men }(n= \\
235)\end{array}$ & & \\
\hline & $\begin{array}{l}\text { Non- } \\
\text { Sarcopenia } \\
(\mathrm{N}=178)\end{array}$ & $\begin{array}{l}\text { Sarcopenia } \\
(\mathrm{N}=87)\end{array}$ & $\begin{array}{l}\mathrm{P}- \\
\text { value }\end{array}$ & $\begin{array}{l}\text { Non- } \\
\text { Sarcopenia } \\
(\mathrm{N}=184)\end{array}$ & $\begin{array}{l}\text { Sarcopenia } \\
(N=51)\end{array}$ & $\begin{array}{l}\text { P- } \\
\text { value }\end{array}$ \\
\hline $\begin{array}{l}\text { Medical history- } \\
\text { hypertension }\end{array}$ & & & 0.519 & & & 0.901 \\
\hline No & 112 (65.5\%) & 59 (34.5\%) & & 115 (77.7\%) & 33 (22.3\%) & \\
\hline Yes & 66 (70.2\%) & $28(29.8 \%)$ & & 69 (79.3\%) & $18(20.7 \%)$ & \\
\hline $\begin{array}{l}\text { Medical history- } \\
\text { diabetes mellitus }\end{array}$ & & & 0.702 & & & 0.352 \\
\hline No & $153(66.5 \%)$ & 77 (33.5\%) & & 154 (77.0\%) & $46(23.0 \%)$ & \\
\hline Yes & 25 (71.4\%) & $10(28.6 \%)$ & & 30 (85.7\%) & $5(14.3 \%)$ & \\
\hline $\begin{array}{l}\text { Medical history- } \\
\text { hyperlipidemia }\end{array}$ & & & 0.207 & & & 0.310 \\
\hline No & 129 (64.8\%) & 70 (35.2\%) & & $153(76.9 \%)$ & $46(23.1 \%)$ & \\
\hline Yes & 49 (74.2\%) & $17(25.8 \%)$ & & 31 (86.1\%) & $5(13.9 \%)$ & \\
\hline $\begin{array}{l}\text { Medical history- } \\
\text { cardiovascular } \\
\text { disease }\end{array}$ & & & 0.493 & & & 0.018 \\
\hline No & 169 (67.9\%) & $80(32.1 \%)$ & & $166(81.0 \%)$ & 39 (19.0\%) & \\
\hline Yes & $9(56.2 \%)$ & 7 (43.8\%) & & $18(60.0 \%)$ & $12(40.0 \%)$ & \\
\hline $\begin{array}{l}\text { Medical history- } \\
\text { heart disease }\end{array}$ & & & 0.212 & & & 0.157 \\
\hline No & $162(68.6 \%)$ & 74 (31.4\%) & & $162(76.8 \%)$ & 49 (23.2\%) & \\
\hline Yes & $16(55.2 \%)$ & 13 (44.8\%) & & $22(91.7 \%)$ & $2(8.3 \%)$ & \\
\hline
\end{tabular}


Table 3

Comparisons of covariates in non-sarcopenia and sarcopenia participants according to the 2019 AWGS diagnostic criteria of sarcopenia (Continued)

\begin{tabular}{|c|c|c|c|c|c|c|}
\hline & \multicolumn{3}{|c|}{ Women $(n=265)$} & \multicolumn{3}{|l|}{ Men $(n=235)$} \\
\hline & $\begin{array}{l}\text { Non- } \\
\text { Sarcopenia (N } \\
=178)\end{array}$ & $\begin{array}{l}\text { Sarcopenia } \\
(\mathrm{N}=87)\end{array}$ & $\begin{array}{l}\mathrm{P} \text { - } \\
\text { value }\end{array}$ & $\begin{array}{l}\text { Non- } \\
\text { Sarcopenia (N } \\
=184)\end{array}$ & $\begin{array}{l}\text { Sarcopenia } \\
(\mathrm{N}=51)\end{array}$ & $\begin{array}{l}\mathrm{P} \text { - } \\
\text { value }\end{array}$ \\
\hline Age & $72.0(6.12)$ & $75.8(6.74)$ & $\begin{array}{l}< \\
0.0001\end{array}$ & $73.4(6.10)$ & $78.9(7.24)$ & $\begin{array}{l}< \\
0.0001\end{array}$ \\
\hline BMI & $24.3(3.37)$ & $22.0(2.63)$ & $\begin{array}{l}<.0001 \\
0 .\end{array}$ & $24.5(3.13)$ & $22.3(2.38)$ & $\begin{array}{l}< \\
0.0001\end{array}$ \\
\hline Albumin & $4.42(0.25)$ & $4.36(0.23)$ & 0.058 & $4.40(0.235)$ & $\begin{array}{l}4.31 \\
(0.235)\end{array}$ & 0.011 \\
\hline Uric acid & $5.08(1.20)$ & $4.97(1.19)$ & 0.490 & $6.07(1.34)$ & $5.95(1.59)$ & 0.610 \\
\hline $\begin{array}{l}\text { Total } \\
\text { cholesterol }\end{array}$ & $186.2(31.4)$ & $191.5(31.4)$ & 0.198 & $173.8(29.3)$ & $\begin{array}{l}167.1 \\
(33.1)\end{array}$ & 0.164 \\
\hline FPG & $104.1(21.7)$ & $101.7(21.8)$ & 0.402 & $103.7(20.4)$ & $\begin{array}{l}102.8 \\
(18.7)\end{array}$ & 0.773 \\
\hline LDL-C & $104.6(27.9)$ & $108.3(29.9)$ & 0.326 & $101.3(26.8)$ & $94.8(28.1)$ & 0.132 \\
\hline HDL-C & $58.6(14.0)$ & $60.8(14.9)$ & 0.227 & $51.2(11.7)$ & $53.8(14.7)$ & 0.182 \\
\hline Triglyceride & $114.9(50.9)$ & $112.1(51.1)$ & 0.679 & $106.2(51.1)$ & $92.2(40.6)$ & 0.072 \\
\hline Hemoglobin & $13.0(1.18)$ & $13.0(0.98)$ & 0.982 & $14.1(1.34)$ & $13.2(1.22)$ & $<.0001$ \\
\hline
\end{tabular}


Table 4

Adjusted model for associated factors of sarcopenia in the study population according to the 2019 AWGS diagnostic criteria of sarcopenia ${ }^{a}$

\begin{tabular}{|c|c|c|c|c|}
\hline & Women & & Men & \\
\hline & $\begin{array}{l}\text { Adjusted Model Odds Ratio } \\
(95 \% \mathrm{Cl})\end{array}$ & $\begin{array}{l}P \text { - } \\
\text { value }\end{array}$ & $\begin{array}{l}\text { Adjusted } \\
\text { Model }\end{array}$ & $\begin{array}{l}\mathrm{P}- \\
\text { value }\end{array}$ \\
\hline & & & $\begin{array}{l}\text { Odds Ratio } \\
(95 \% \mathrm{Cl})\end{array}$ & \\
\hline Moderate to High PA & $0.52(0.27,0.98)$ & 0.043 & $\begin{array}{l}0.34(0.12 \\
0.95)\end{array}$ & 0.039 \\
\hline Age & $1.11(1.06,1.17)$ & $\begin{array}{l}< \\
0.0001\end{array}$ & $\begin{array}{l}1.12(1.05 \\
1.18)\end{array}$ & 0.0002 \\
\hline BMI & $0.73(0.65,0.81)$ & $<.0001$ & $\begin{array}{l}0.75(0.65 \\
0.87)\end{array}$ & 0.0001 \\
\hline Albumin & $0.37(0.10,1.40)$ & 0.143 & - & - \\
\hline Hemoglobin & $1.28(0.96,1.7)$ & 0.092 & - & - \\
\hline $\begin{array}{l}\text { Medical history of } \\
\text { cardiovascular disease }\end{array}$ & - & - & $\begin{array}{l}2.43(0.90 \\
6.55)\end{array}$ & 0.080 \\
\hline Medical history of heart disease & - & - & $\begin{array}{l}0.21(0.04 \\
1.20)\end{array}$ & 0.079 \\
\hline Institutionalization & - & - & $\begin{array}{l}2.94(0.97 \\
8.90)\end{array}$ & 0.057 \\
\hline
\end{tabular}

Figures 


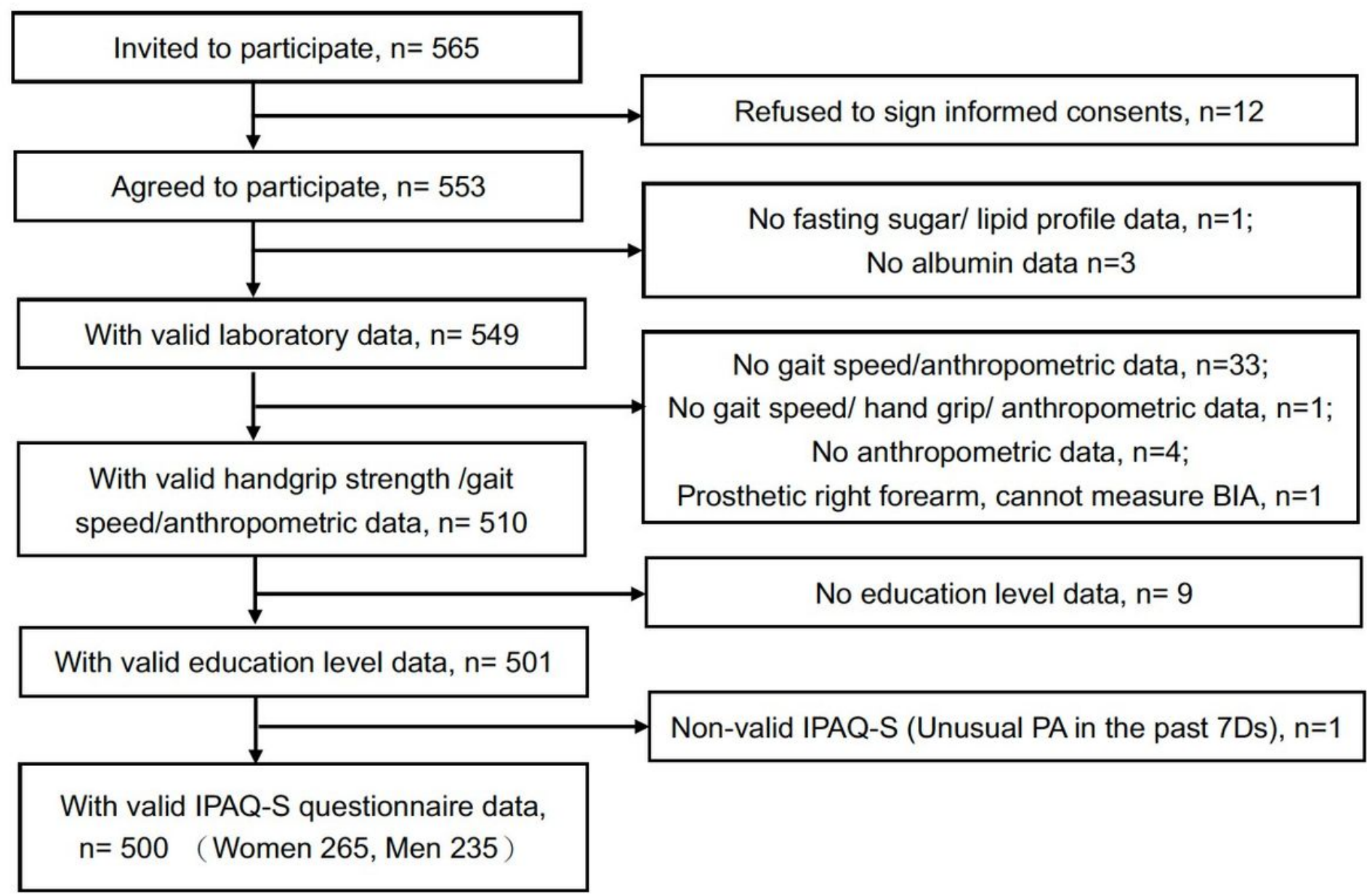

Figure 1

Study flowchart 